\title{
INTEGRATING INTERFAITH DIALOGUE AND ECONOMIC EMPOWERMENT: A Study on Interfaith Women Community Srili Yogyakarta
}

\author{
Wiwin Siti Aminah Rohmawati \\ Institut Agama Islam Darussalam (IAID) Ciamis, Indonesia \\ E-mail: wiwinrohmawati@iaid.ac.id \\ Kamilia Hamidah \\ Institut Pesantren Mathaliul Falah (IPMAFA) Pati, Indonesia \\ E-mail: kamiliahamidah@ipmafa.ac.id \\ Erin Gayatri \\ Srikandi Lintas Iman Yogyakarta, Indonesia \\ E-mail: gayatri.erin@yahoo.co.id
}

\begin{abstract}
The COVID-19 pandemic has affected nearly every aspect of life, particularly in the economic sector and micro, small, and medium enterprises (MSMEs) - the vast majority of whom are women. Women are also among the most vulnerable populations to the COVID-19 pandemic. Srikandi Lintas Iman (SRILI) is a women's community that has been doing interfaith dialogue since 2015. SRILI has been and continues to carry out economic empowerment of ummah to strengthen interfaith women's solidarity in the face of the COVID-19 pandemic. One of SRILI's economic empowerment projects is the management of the Srili Bakoelan Online Market and the Nglarisi Dagangan Teman (buying friend's products) movement through social media. This is qualitative research aimed at addressing two major questions: how to approach and organize the program and how it promotes the personal transformation of the SRILI Bakoelan community as well as the development of creative economic potential in the family and religious communities. The findings of the study indicate that social solidarity, social linking, and social bonding are valuable assets that a community may use to always be adaptive in providing a place for interfaith dialogue and response to social problems.
\end{abstract}

Keywords: SRILI; Interfaith Dialogue; Community Economic Empowerment; Community Resilience; Interfaith Women's Community; COVID-19.

Article history: Received: 04 June 2021; Revised: 11 July 2021; Accapted: 
05 August 2021; Available online: 01 September 2021

\section{How to cite this article:}

Rohmawati, Wiwin Siti Aminah, Kamilia Hamidah, and Erin Gayatri. "Integrating Interfaith Dialogue and Economic Empowerment: A Study on Interfaith Women Community Srili Yogyakarta". Religio: Jurnal Studi Agama-agama 11, no. 2 (2021): 140-165. https://doi.org/10.15642/religio.v11i2.1767

\section{Introduction}

The COVID-19 pandemic has had a significant impact on almost every aspect of society-particularly the economic sector. Many experts predict that the economic impact of this pandemic will be even worse than the global financial crisis of 2008 and 2009. The global economy declined by $4.4 \%$ because of limited investment in international markets, which had a negative impact on Indonesia's economic growth. According to the National Development Planning Agency (BAPPENAS), the number of unemployed people could rise to 4.22 million due to the pandemic. ${ }^{1}$

The pandemic has also had a significant impact on Indonesian micro, small, and medium enterprises (MSMEs), also known as UMKM (Usaba Mikro, Kecil dan Menengah). According to the Ministry of Cooperatives and SMEs of The Republic of Indonesia, there were nearly 64.2 million MSMEs (99 percent of all business units) in 2018, which employed almost 117 million employees (97 percent of the total workforce in the economic sector), contributing 61.07 percent of the gross domestic product nationwide. ${ }^{2}$ Based on the current research conducted by UN Women and Pulse Lab Jakarta, many women entrepreneurs and MSMEs owned or managed by women have adopted digital platforms and online technologies as one of the strategies to mitigate the pandemic. As a result, 54 percent of women who own MSMEs now sell their products online. However, sociocultural gender inequality causes digital gender gap among men and women entrepreneurs.

\footnotetext{
1 Ikfina Chairani, "Dampak Pandemi COVID-19 dalam Perspektif Gender di Indonesia," Jurnal Kependudukan Indonesia, Edisi Khusus Demografi dan COVID-19, (July, 2020): 39-42.

2 Dani Sugiri, "Menyelamatkan Usaha Mikro, Kecil dan Menengah dari Dampak Pandemi Covid-19”, Fokus Bisnis: Media Pengkajian Manajemen dan Akuntansi, 19 (1), (2020): 76-86. http://doi:10.32639/fokusbisnis.v19i1.575
} 
Women are especially vulnerable to adverse economic effects from the COVID-19 pandemic. UN Women outlines five indicators as well as their underlying causes. First, part-time, and temporary workers, the large majority of whom are women, are likely to lose their jobs. Second, most working women (58 percent) work in the informal sector, which offers little or no social protection. Third, because the scale of business mostly small, they depend more on their own financing, women-owned businesses are more likely to fail. Fourth, discriminatory gender norms often prevent women business owners from accessing government funds and assistance from financial institutions. Fifth, despite the development of IT, there remains a digital divide between men and women in terms of accessing and using them. ${ }^{3}$ As reported by UN Women, the Alliance of Independent Journalists Jakarta, and Indosat Ooredoo, the pandemic has exacerbated gender inequality, making women more vulnerable. ${ }^{4}$ Indonesia's Minister of Women's Empowerment and Child Protection said in a statement that women have become much more vulnerable since the outbreak started, including losing their livelihoods, female dual role and increasing gender-based violence. ${ }^{5}$ According to data from the Online Information System for the Protection of Women and Children (SIMFONI PPA), there were 105 cases of violence against women from March 14 to April 22, 2020, and 67 of them were cases of domestic violence. ${ }^{6}$

The government issued a National Economic Recovery policy to address COVID-19 for MSMEs starting in August 2020. Several

${ }^{3}$ UN Women, Policy Brief No. 15, "Addressing the Economic Fallout of Covid-19: Pathways And Policy Options For A Gender-Responsive Recovery," (2020). https://www.unwomen.org/en/digital-library/publications/2020/06/policy-briefaddressing-the-economic-fallout-of-covid-19

${ }^{4}$ UN Women and Indosat Ooredo, "Menilai Dampak Covid-19 terhadap Gender dan Pencapaian Tujuan Pembangunan Berkelanjutan di Indonesia," (2020). https://data.unwomen.org/sites/default/files/inline-files/Report_Counting\%20the $\% 20$ Costs $\% 20$ of $\% 20$ COVID-19_Bahasa.pdf

5 Ministry of Woman's Empowerment and Child Protection (KPPA), "Survei Menilai Dampak COVID-19," https://kemenpppa.go.id/index.php/page / read/29/2921/survei-menilai-dampak-covid-19-perempuan-memikul-beban-lebihberat-dibandingkan-laki-laki (accessed 24 October 2020).

6 Ministry of Woman's Empowerment and Child Protection (KPPA), "KDRT Mengintai di Tengah Pandemi," https://www.kemenpppa.go.id/index.php/page $/ \mathrm{read} / 31 / 2707 /$ kdrt-mengintai-di-tengah-pandemi (accessed 31 May 2020); the National Commission of Woman, "Kajian Respon Cepat," (accessed 16 November 2020). 
communities, including The NU Cares for COVID-19 Task Force, the Muhammadiyah COVID-19 Command Center (MCCC), the Church Against COVID-19 (GMC), and the Catholic Network Against COVID-19 (JKMC-19) organized a solidarity effort to mitigate the pandemic's impact. There are also interfaith-based initiatives that provided direct assistance to people affected by the pandemic, for example, the Gusdurian Networks and Srikandi Lintas Iman (SRILI).

Few studies address civil society groups' efforts to mitigate the COVID-19 pandemic, particularly focusing on interfaith women's MSME. This paper aimed to address this gap by examining SRILI's efforts in responding to the pandemic's impact. SRILI is a Yogyakarta-based interfaith women's group that established on August 29, 2015. SRILI currently comprises more than 200 members from different socioeconomic, ethnic, educational, age, and religious backgrounds. Based on SRILI's internal survey taken between April 8-10, 2020, assessing the impact of COVID-19, 33.4 percent of respondents stated they had lost a source of income and 8 percent stated their income had dropped significantly. Respondents proposed solutions to these economic difficulties, such as starting a business with fellow SRILI members, advertising products online, buying friends' products, and exercise economic empowerment.

In response, SRILI organized an economic empowerment program, supported financially by Indika Foundation. This initiative intends to strengthen and sustain interfaith women's businesses, primarily SRILI members, during a pandemic. A series of online seminars and trainings were held, including training about how to create social media content, an online market for the Facebook Fanpage "Pasar Online SRILI Bakoelan," (SRILI Bakoelan Online Market) and the "Nglarisi Dagangan Teman" (buying friend's products) movement. SRILI Bakoelan initially utilized a WhatsApp group, which was created on May 12, 2020, though they later created a Facebook page and Instagram account. This program ought to be explored because it is an economic empowerment movement carried out at the grassroots level and is unique in that it involves MSME women business owners who are cross-generational, interfaith, and cross-regional.

SRILI's economic empowerment program is community-based and promotes strengthening community resilience. It also provides a 
space for dialogue and interaction for women of various identities and backgrounds. The National Digital Consultation on the National Action Plan for the Protection and Empowerment of Women and Children in Social Conflict (RAN P3AKS) explains that,

"Economic empowerment has the possibility to not only promote wellbeing, but also to function as a social hub, to encourage dialogue, to break social barriers, and, as a result, to contribute to the reduction of conflict and the promotion of peace. Women's economic empowerment will promote more equitable power dynamics in the home or community. This will have implications in term of reducing the possibility of domestic violence and improving family income. Economic empowerment encourages women to actively participate in society and contribute to community cohesion by using economic cooperation as a means of communication across communities."7

Moreover, this research is significant in the perspective of the development of the concept of ummah or community. In general, the widely promoted concept of ummah's economy remains quite exclusive to Muslims, whereas Indonesian society is religiously diverse. Therefore, the concept of ummah's economy should be more inclusive. The SRILI program is a grassroots community project aimed at minimizing the impacts of COVID-19 through a creative and inclusive approach to community economic development.

The role of women in disaster resilience is highlighted in the Handbook of Disaster Risk Reduction and Management. This handbook examines how women are an invisible force of resilience. ${ }^{8}$ This study expands on the pattern of women's resistance to catastrophes, but it does not directly address identity-based vulnerabilities. Women play a critical role in promoting social resilience because the sphere of care, prevention, and caregiving have culturally become the domain of women. Nair and Tamara ${ }^{9}$ explored the consequences of COVID-19 on women from various perspectives, including the economic vulnerability of women in the informal sector-one of the sectors most affected by the pandemic.

\footnotetext{
7 https://wps-indonesia.com/rekomendasi-publik/, (accessed 16 November 2020).

8 Christian N. H Madu and Cua-Hua Kuei, ed., Handbook of Disaster Risk Reduction and Management (Singapore: WSPC, 2018).

9 S. Nanthini Nair and Tamara, "COVID-19 and the Impacts on Women," NTS Insight, No. IN20-05, RSIS Centre for Non-Traditional Security Studies (NTS Centre) Nanyang Technological University Singapore, (2020).
} 
Their research, however, did not explicitly emphasize how the pandemic affected women of majority vs. minority identities, which will be explored in the context of SRILI Bakoelan.

Drolet underlines how women are simultaneously a vulnerable group as well as an important player in the post-disaster recovery process. ${ }^{10}$ Juita examined the role of mobile vegetable traders in supporting family economic resilience in the context of the pandemic. ${ }^{11}$ While highlighting the vulnerabilities of these women, the research shows the adaptability of these mobile merchants to overcome the challenges and obstacles they meet.

Amri highlighted a significant drop in turnover from MSMEs due to the pandemic and the significance of digital platforms in the expansion of MSMEs. ${ }^{12}$ According to Sugiri, the government's effectiveness in assisting and developing MSMEs in the middle of a pandemic must be supported by both short-term and long-term strategies to ensure the survival of MSMEs. ${ }^{13}$ These two studies do not respond to the specific impact of the pandemic on MSMEs owned or run by women, or the efforts made by the community, especially women, to respond to the pandemic's impact.

Meanwhile, there have been numerous studies on SRILI. An article by Wahyuningtyas underlined the role of SRILI in voicing and creating peace through the creation of meeting spaces, particularly for women of intersecting marginalized identities, ranging from housewives to religious figures. ${ }^{14}$ Sa'adah addresses SRILI's role in promoting religious harmony by organizing a variety of activities that

10 Julie Drolet et. al., "Women Rebuilding Lives Post-Disaster: Innovative Community Practices for Building Resilience and Promoting Sustainable Development," Journal Gender \& Development, vol. 3 (3), (2015).

11 Florentina Juita, "Peran Perempuan Pedagang Sayur Keliling dalam Menopang Ekonomi Keluaga pada Masa Pandemi COVID-19 di Kelurahan Pagesangan Kecamatan Mataram Kota Mataram." CIVICUS: Pendidikan-Penelitian-Pengabdian, Pendidikan Pancasila dan Kewarganegaraan, 8 (2), (September, 2020): 100-107.

12 Andi Amri, "Dampak Covid-19 Terhadap UMKM di Indonesia," Jurnal Brand, P 123-130, 2020. https://ejournals.umma.ac.id/index.php/brand/article/view/605.

13 Dani Sugiri, "Menyelamatkan Usaha Mikro, Kecil dan Menengah dari Dampak Pandemi Covid-19," Jurnal Fokus Bisnis: Media Pengkajian Manajemen dan Akuntansi, vol 19, no 1, (2020): 76-86. http://doi.org/10.32639/fokusbisnis.v19i1.575

14 Retno Wahyuningtyas, Sari Perdanawati and Nur Maulida, "Srikandi Lintas Iman: Praktik Gerakan Perempuan dalam Menyuarakan Perdamaian di Yogyakarta," Jurnal Sosiologi Reflektif, vol.13 (2), (2020): 293-312. 
are essential for the community. ${ }^{15}$ Using Glock and Stark's sociological theory of religiosity and Tiliouine and Belgoumidi's realm of religiosity, Noor concluded that SRILI's activities and initiatives have either directly or indirectly contributed to the religiousness of its members, especially Muslim women. ${ }^{16}$ The research done by Pongpindan examines SRILI's spirituality through Hamka's contemporary Sufism approach as a type of religious moderation based on compassion among religious people amid Indonesia's diversity. ${ }^{17}$ This thesis concludes that the SRILI community's generosity is demonstrated by the balance of soul and body, mind and religion, openness, the struggle for equality and justice, courage, and balance in the world, and the hereafter. All the research above has not yet touched on the SRILI's efforts to respond to the COVID-19 pandemic.

This paper aims to answer two research questions: (1) how is ummah economic empowerment carried out by SRILI Bakoelan during the COVID-19 pandemic and (2) what is the effect of SRILI Bakoelan's economic empowerment on the self-development of SRILI Bakoelers (the seller) and the potential of the creative economy in families and religious communities?

This is qualitative research under which the data is presented in the form of a descriptive narrative. The research data was gathered both offline in Yogyakarta and online through the Zoom platform. Data collection is based on SRILI's activity reports and digital analysis of all SRILI's social media activities, including Facebook, Instagram, their website, and WhatsApp groups (Srikandi Lintas Iman and SRILI Bakoelan). The interviewees are key SRILI members and members of SRILI Bakoelan.

This research utilizes an interactive Miles and Huberman model in the analysis and data validation processes, which consists of four

15 Sokhibatul Sa'adah, "Peran Komunitas Srikandi Lintas Iman (Srili) Dalam Berpartisipasi Menciptakan Perdamaian Antar Umat Beragama Di Yogyakarta," (A thesis of under-graduate program, the Faculty of Theology and Islamic Thought, UIN Sunan Kalijaga, Yogyakarta, 2019).

16 Nina Mariani Noor, "Srikandi Lintas Iman: Religiosity in Diversity," Journal Research in the Social Scientific Study of Religion, vol. 30, (2019): 181-192. http://doi:10.1163/9789004416987_011

17 Alfriyani Pongpindan, "Srikandi Lintas Iman di Yogyakarta: Sebuah Model Spiritualitas Keugaharian dalam Moderasi Beragama," (a thesis at Interdisciplinary Islamic Studies, Graduate Program, UIN Sunan Kalijaga, Yogyakarta, 2020). 
stages: data collection, data reduction, data presentation, and conclusion drawing. ${ }^{18}$ The researcher presents the results or answers to the formulation of the problem at the beginning of the process of drawing conclusions, which generates relevant data. It even generates new theories or research that may be utilized to address problems and improve people's lives.

\section{Community Economic Empowerment and Development}

The term empower has two definitions in the Webster and Oxford English Dictionary. First is "to provide power or authority to or to grant power, transfer power, or delegate authority to other parties", and the second is "to give ability to or enable or seek to give ability." ${ }^{\prime 19}$ Empowerment is a process carried out by the community itself; it may be defined as a process in which a community not only generates employment, raises revenue, or improves infrastructure, but more significantly, enables the community to manage change. According to Cavaye, the notion of community empowerment combines two major ideas: community and development. ${ }^{20} \mathrm{~A}$ community is a group of people who have a shared bond; thus, interaction and joint activities are highly important for community development. While development is the process of expanding opportunities, widening options, treating difficulties as a source of inspiration (thinking outside the box), and anticipating change. Therefore, progress requires change, the vitality of which is aimed at improving participation, flexibility, equity, attitudes, institutional functioning, and quality of life. ${ }^{21}$

When community and development are combined, it might be interpreted that the community itself is participating in a process aimed at improving the community's social, economic, and environmental conditions. As a result, the community has a dual purpose: it serves as both a tool and a goal for community growth.

18 M. B. Huberman, Qualitative Data Analysis: A Source Book of New Methods (London: Sage Publication, 1998).

19 Meriam Webster Online Dictionary, https://www.merriamwebster.com/dictionary/empower

20 Jim Cavaye, "Understanding Community Development," www.communitydevelopment.com.au

21 Mary Emery and Cornelia Flora, "Spiraling-Up: Mapping Community Transformation with Community Capitals Framework," Community Development, 37/1, (2006): 19-35. DOI: 10.1080/15575330609490152. 
Because the community works together, and collective action strengthens this community, as well as economic ties, which has an impact on expanding access and range of opportunities. Thus, the notion of community development is essentially enhancing the group's ability to collectively make better decisions in empowering the community's resources.

Examining the programs conducted by SRILI prior to the pandemic provides a clearer picture of how the dynamics of the activities which have been run are very contextual. Furthermore, referring to Fatihaturrohmah and Ichsan, activities like interfaith dialogue, interfaith visits to places of worship, and conflict resolution training could help to strengthen multicultural perspectives. ${ }^{22}$ The solidarity of the SRILI community emerged from the community's common vision and mission, which became a common identity as well as the principal of social capital in generating resilience. This social capital works as a catalyst in the development of programs aimed at increasing possibilities, diversity, and converting challenges into sources of inspiration. Various programs aimed at assisting its members were established long before the coronavirus pandemic, and because of these programs, members were far more capable of forming strong social bonds.

\section{COVID-19 Pandemic, Economic Empowerment and Community Resilience of SRILI Bakoelan}

In SRILI's internal survey on the impact of the, both student and non-student respondents felt the pandemic had impacted their ability to fulfil everyday needs, such as the need for greater internet quotas, resulting in a reduction in tertiary needs. According to this survey, 51.6 percent did not lose their source of income, 33.4 percent did lose their source of income, 4.7 percent would lose their income if their scholarship were terminated, and 8 percent experienced a significant decrease in income. This survey report shows the pandemic's influence on the vulnerability of SRILI's members' household income sources. This assessment led to the creation of economic empowerment programs aimed at developing the SRILI communities, particularly for the affected members. This initiative is a

\footnotetext{
22 Fatihaturrohmah and Ahmad Shofiyuddin Ichsan, "Gerakan Komunitas Perempuan Srikandi Lintas Iman," Jurnal PAI Raden Falah, vol 1 no 4, (2019): 425444.
} 
concrete action of solidarity and empathy. ${ }^{23}$ Furthermore, the pandemic forced everyone to quickly adapt to changing circumstances, including how to keep afloat amid uncertainty. The adaptation process has allowed innovation and new patterns for building resilience.

In response to the COVID-19 pandemic, the SRILI community launched an initiative focusing on economic development. Thus, the WhatsApp group "SRILI Bakoelan" was formed in May 2020, regardless of the fact that economic empowerment activity in Bakoelan (buy and sell) had previously been carried out with the movement of "Nglarisi Dagangan Teman" (buying friend's products). Although it has not been properly structured, this movement strengthened community solidarity. This, in turn, stimulated innovative creativity by developing economic empowerment programs. ${ }^{24}$

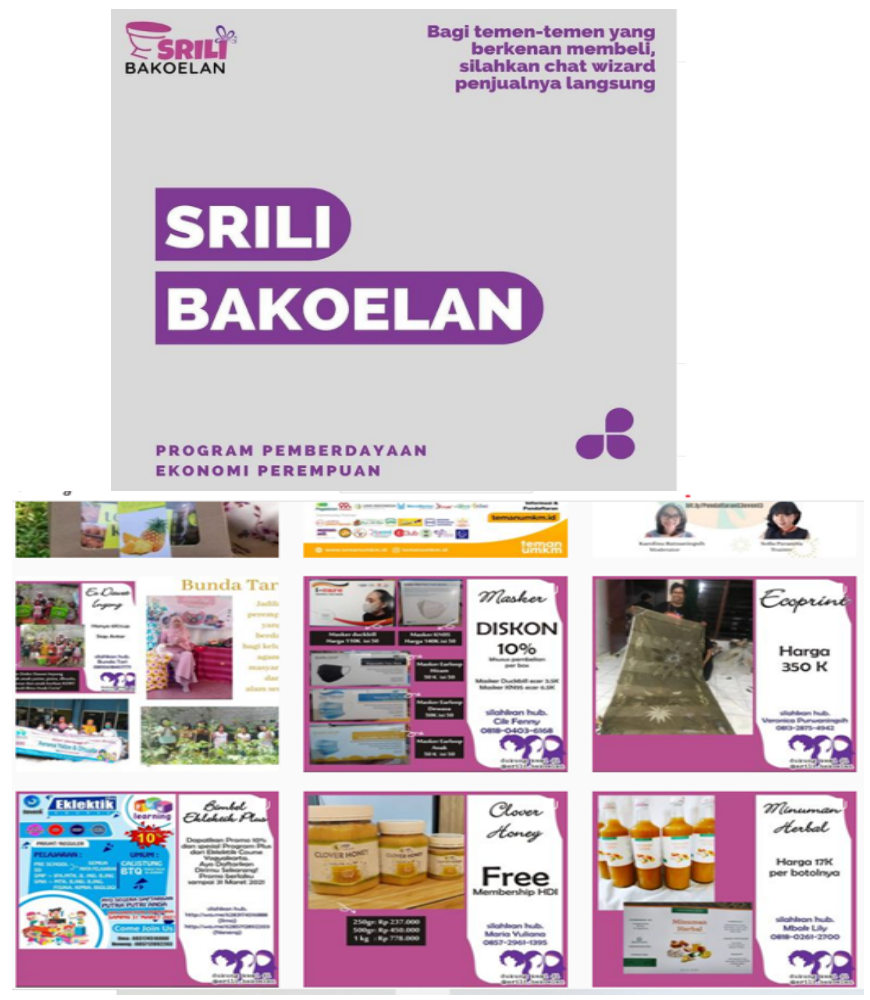

${ }^{23}$ Based on the SRILI internal survey report, 2021.

24 Wiwin S.A. Rohmawati, Kamilia Hamidah and Erin Gayatri, "Understanding the Srili Bakoelan," FGD at Legend Café, 20 March 2021. 
Figure 01: This is an example of SRILI Bakoelan products. (Source: https://www.instagram.com/SRILI_bakoelan/)

A series of online economic empowerment workshops were held to encourage interfaith women's MSME owners to continue to survive and persevere. The group organized a series of online events, demonstrating the community's flexibility in facing the pandemic. A comprehensive economic empowerment program was implemented, starting with capacity building, skill development, IT training, and the formation of online marketplaces on their Facebook page, which was launched in July 2020.

The series of programs were organized in a structured and continuous approach. In practice, these programs were not just targeting SRILI members but also the public. This shows the SRILI community's concern for societal problems in general. The empowerment program, in addition to webinars via Zoom, includes social media content such as posters, infographics, photo captions, microblogs, and videos, which are all freely accessible via SRILI's social media.
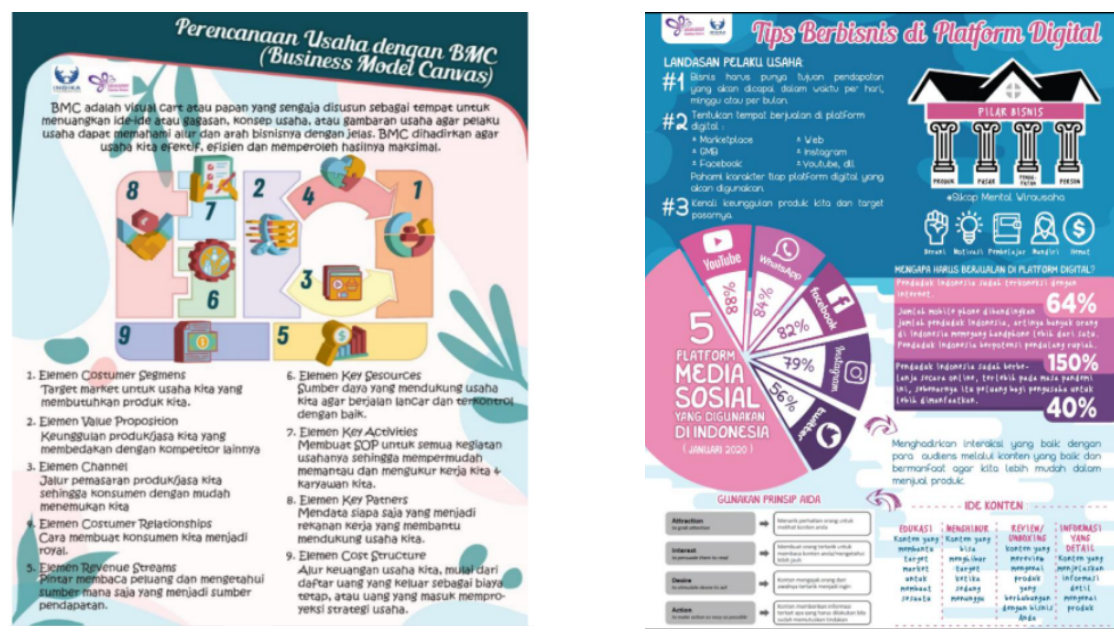

Figure 02:

The content of SRILI Bakoelan's social media (Source: https://www.facebook.com/SRILIjogja)

SRILI's economic empowerment program not only presents online mentoring platforms, but also serves people with disabilities, 
whose presence is sometimes not facilitated in virtual forums. SRILI's webinars always involve a Sign Language Interpreter for the deaf. As stated by Februarti, a deaf participant:

"The program is good, so it can help the needy. I am interested since this program will teach us how to sell and what sort of marketing to utilize. In addition, most of the information in the SRILI Bakoelan community comes from friends who join. Then, throughout the training. The deaf had access to a translator. Because I have access to information, it has a greater influence. I learned a lot from watching this presentation." 25

This demonstrates how SRILI cares for marginalized groups, who are sometimes overlooked by online empowerment programs.

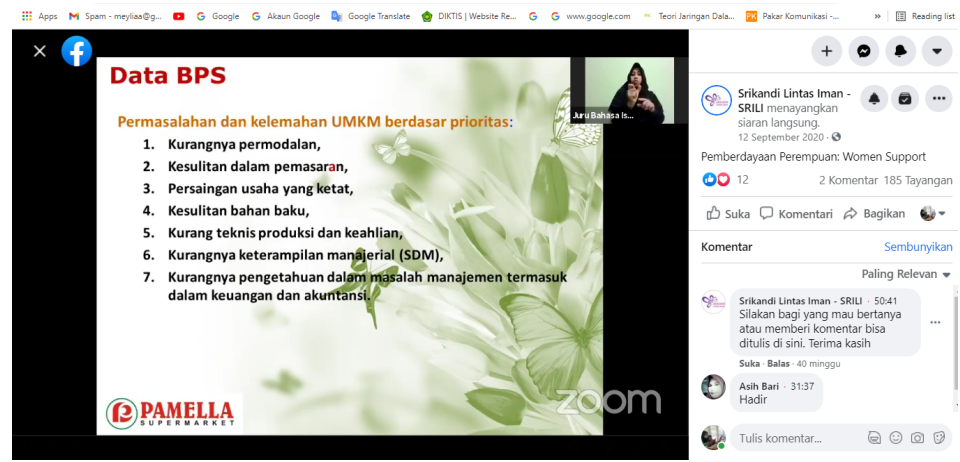

Figure 03:

A sign language interpreter at one of the online seminar activities (Source: https://www.facebook.com/SRILIjogja)

According to the interviews, the participants of this program generally responded positively to SRILI's economic empowerment programs. Some of the positive responses have an impact not only on individuals but also on their families and communities. Lilin from Penghayat Community said:

"We can certainly learn more from other friends who have more established businesses. If SRILI has a member who is less active, they give me more credit and are more familiar. I wish to convey SRILI knowledge to the Penghayats community as well, because if we already own a business, our community group can be self-sufficient." ${ }^{, 6}$

${ }_{25}$ Dwi Rahayu Februarti, interview, 18 April 2021.

${ }^{26}$ Lilin Kurniati, interview, 11 April 2021. 
The strength of the SRILI Bakoelan program, according to Mustaghfiroh Rahayu (Ayu), one of the co-founders of SRILI, is in its continuous learning activities. Ayu acknowledges that she has learned a lot about online marketing because of this learning experience. Furthermore, she mentioned that SRILI Bakolen's programs are quite accessible, so there is not a steep learning process for beginners who want to participate. She said:

"SRILI's economic development program is distinct as compare with others community economic program alike. Its distinction lies on its program which is grounded knowledge and training material are simple and easy to understand for me as beginner. I feel comfortable to share and I learnt a lot from that experience. Another uniqueness of SRILI economic development programs is continuous and sustainable. The community then always support even the formal program has been concluded." 27

Department for International Development described resilience as "the capacity of a system, group, or society exposed to a hazard to resist, absorb, accommodate, and recover from the effects of a crisis in a timely and effective manner." ${ }^{28}$ The Intergovernmental Panel on Climate Change defines resilience as "the ability of a social or ecological system to absorb shocks while retaining the same fundamental structures and ways of functioning, the capacity for selforganization, and the capacity to adapt to stress and change." ${ }^{29}$ According to these definitions, the SRILI Bakoelan program can demonstrate a way adapting that can translate into other contextual empowerment initiatives.

One way the group is innovating is by addressing generation gaps, which are sometimes exacerbated by older users' difficulties of adapting to digital platforms. However, the SRILI economic empowerment initiative has effectively mitigated the risk. The creative content produced on SRILI's social media proves this. Both product material from Bakoelers in the form of digital flyers, as well as

\footnotetext{
27 Mustaghfiroh Rahayu, interview, 11 April 2021.

28 Department for International Development, "Defining Resilience," A DFID Approach Paper, (United Kingdom, 2011). https://reliefweb.int/sites/reliefweb.int /files/resources/Defining-Disaster-Resilience-summary_0.pdf

29 The Intergovernmental Panel on Climate Change (IPPC), Managing the Risks of Extreme Events and Disasters to Advance Climate Change Adaptation (New York: Cambridge University Press, 2012).
} 
infographics on SRILI Bakoelan activities, were uploaded on various SRILI social media platforms.

This is where the SRILI community's ideal vision of ummah economic growth in a broad sense may be reproduced by other communities. People's economic growth, in which social solidarity is the key capital in constructing social bonding, can encourage the community to be more sensitive to current issues and adjusting, and then translating them into implementable programs.

\section{Community Economic Development and Interfaith Dialogue}

Community Economic Development (CED) is a continuous process of community assistance and implementation techniques in improving a community's economy, both at the macro and micro levels. CED may be divided into three stages: (1) generating economic possibilities, (2) eliminating negative perceptions, and (3) promoting higher purchasing power and investment. CED has two major goals: First, improving the community's economic situation (income and disposable assets) and local enterprises. Second, enhancing the overall quality of life in the neighborhood, whether through appearance, security, or social networks, and to generate good growth. ${ }^{30}$

In its implementation, CED involves developing human resource capacity, whether managerial, institutional, entrepreneurial or knowledge of capital access, as well as facilitating technology skills. Meanwhile, several programs have been implemented to increase business productivity, including those related to the community business development process, facilitating various efforts that contribute to greater community economic business productivity, and providing training in terms of accessing a larger market by incorporating digital technology efficiently.

Before exploring SRILI's practice of CED, it is necessary to underline the study's limitations in terms of community understanding. Selo Soemarjan's definition of "local community," refers to residents of a village, city, ethnic group, or nation, with emphasis on the existence of social relationships among the group members. ${ }^{31}$ In this sense, the community refers to the segment of

\footnotetext{
${ }^{30}$ Mihailo Temali, The Community Economic Development Handbook (USA: Amherst H. Wilder Foundation, 2002), 2-14.

31 Selo Soemarjan, Social Change in Yogyakarta (New York: Cornel University Press, 1962), 20-21.
} 
society that lives in a certain region. The argument in this context is undoubtedly connected to the concept of social connection. Diamond highlights a debate about the concept of community, in which some believe that community members should live in the same region, while others claim that they can be geographically dispersed. ${ }^{32}$

With technological advancement, community is no longer confined to the scope of face-to-face social contact or geography; rather, its definition has broadened with the introduction of "digital communities." Solidarity may be created not just in geographical boundaries but also through digital connectivity. A virtual community, according to Rheingold, is a collection of individuals who may never meet in person but communicate words and ideas over a digital network. Thus, community emotion is limited down to three binding components: solidarity, sharing, and mutual need. ${ }^{33}$

Meanwhile, the word ummah, which first appeared in the Prophet Muhammad's Medina Charter, is a notion that has no territorial bounds. The notion of the ummah in this constitution was unity, integration, and solidarity, and it was a binding pact for all the people of Medina, which at the time was not just populated by Muslims. ${ }^{34}$ This inclusive community binds SRILI, which is united by the community's vision and mission as the driving force behind various initiatives, the goals of which not only aimed at specific religious targets or groups but at anyone who wishes to be a part of the community.

The SRILI's economic empowerment initiatives did not only target the Bakoelers, who are members of SRILI but also offered other participants who are not members of SRILI chances. The SRILI Bakoelan program has become more structured and focused because of this initiative. One of the outcomes is that an expanding number of different MSMEs groups want to join the SRILI Bakoelan. Subsequently, the SRILI Bakoelan enhanced the Bakoelers' social bonds and opened wider market opportunities, as well as access to

32 Michael Diamond, "Community Economic Development: A Reflection on Community, Power, and the Law," The Jurnal of Small and Emerging Bussiness Law, vol 8, (2004), 153-155.

33 Soerjono Soekanto, Sosiologi Suatu Pengantar (Jakarta: Raja Grafindo Persada, 2014), 130-133.

34 Zakiyuddin Baidhawi, Fikih Kebhinekaan; Piagam Madinah dan Pancasila, PrinsipPrinsip Kehidupan Bersama dalam Berbangsa dan Bernegara (Bandung: Ma'arif Institute and Mizan Pustaka, 2015), 135-143. 
government services. This occurred because of the Nglarisi Dagangan Teman movement and the effort to promote friends' products. As a result, market opportunities emerged within the SRILI community and beyond.

The Bakoelers, their families, and communities have all benefited from this economic development initiative. Among the personal advantages reflected in Bakoelers' perceptions after engaging in these mentoring activities is that this program has helped enhance participants' self-confidence. Another advantage is growing knowledge about the complexities of e-commerce, as well as skills such as identifying company targets and strategies, making marketing plans, business management, managing social media, and overcoming mental blocks. Practically, because of this training, some Bakoelers have begun to utilize social media as a form of internet marketing. The increased of business network and motivation to strive together with fellow women also made a deep impression on the participants of this community economic development program. ${ }^{35}$

Siti Rohmah said that the SRILI economic development program provided her with new marketing expertise, particularly in understanding internet marketing.

"New things I get from SRILI is about marketing techniques.

Before we learn from Mbak Eiz about different digital marketing strategy on Facebook and Instagram. Initially I only think that marketing a product will enough on WhatsApp, but apparently not, I come to know each social media platform has different strategies on marketing, for example on Facebook or Instagram, how much cost for each post, so I learn the way of advertising my product on digital platform. When raw ingredients are unavailable, for example, I must seek for them. To get instant supply, I checked on Facebook for someone who sells chicken and can deliver immediately."

Resti stated that by participating in the SRILI economic development program, she personally felt much more independent, enabling her to contribute financially to support her family. ${ }^{37}$

Meanwhile, some Bakoelers have said that being involved in online businesses has improved family relationships. Nana, a Bakoeler

\footnotetext{
35 Srikandi Lintas Iman, "Narasi Laporan Akhir Program Pemberdayaan Ekonomi Srikandi Lintas Iman," (Yogyakarta, 2020).

36 Siti Rohmah, interview, 11 April 2021.

${ }^{37}$ Resti, interview, 12 April 2021.
} 
and SRILI Bakoelan coordinator, says her family relationships have changed because her son and husband assist in online marketing. The family, which had previously been divided, was re-united through entrepreneurial goals, strengthening the family's togetherness and reduce the marital and family stress. ${ }^{38}$

Additionally, because of the various Bakoelers' backgrounds, this program was offered to the community to strategically motivate other groups to replicate similar initiatives. This also helps Bakoelers' products to be known by a larger and more diversified market. This network growth has had a variety of effects, including increased community networks, and expanded market opportunities, as well as encouraged to create new products. Consequently, multiple effect is felt not only on their personal but on their community. The following are some testimonies given by Bakoelers:

"There is one intriguing aspect about SRILI Bakoelan. Even if I am unable to actively participate, there is one thing I can do, and that is to spread the spirit of SRILI Bakoelan, just like a friend helping a friend or a neighbor helping a neighbor becomes a spirit. That is what I do at church. What I learn at SRILI, I frequently implement at church community." ${ }^{39}$

"The personal advantages of the SRILI program for the economy have been minor. Despite connection, SRILI's knowledge and information was subsequently passed on to the Lajnah Imaillah community, until other members of the community also wanted to join SRILI to market their products. However, it has not been submitted to the administrator." 40

In times of disaster, communal solidarity is the most important pillar in the construction of resilience. With solidarity, innovative and creative efforts may be flexibly transformed into a variety of initiatives to overcome the community's challenges.

\section{SRILI Bakoelan as Space for Dialogue}

Members of SRILI Bakoelan not only assist one another economically but also provide social outlets. From the viewpoint of its members, SRILI Bakoelan is a unique community since it allows its members to interact with one another despite the differences and

\footnotetext{
${ }^{38}$ Nana Karolina, interview, 20 March 2021.

39 Aant, interview, 12 April 2021.

40 Anis, interview, 12 April 2021.
} 
diversity that exist. The question is whether they realized from the outset that SRILI Bakoelan is a part of the dialogue process or if they only realized it after being a part of SRILI Bakoelan.

Bakoelers, who were already SRILI members, certainly recognize and understand that SRILI Bakoelan is a forum for interfaith dialogue but is less clear for new members. When they express a willingness to participate in the interfaith-based women's economic empowerment program, they tacitly recognize that their involvement in these activities would involve people of many identities. Participation in collaborative programs with individuals of other religions or ethnicities is an essential part of dialogue. Therefore, it is important to dive further into the informants' perspectives on diversity and interreligious dialogue.

In terms of comprehending diversity, the informants have a different point of view. Diversity, according to Yulistia, must be acknowledged, which necessitates communication. ${ }^{41}$ Yohana, a Catholic SRILI member, agreed, stating: 'Diversity is something fascinating that makes us think more positively and something we can't resist." $^{\text {"42 }}$

The difference is something lovely when lived and experienced. Lilin, of the Penghayat community, claimed that when she was younger, she went to Kanisius Elementary School (Catholic Foundation), and her classmates looked up to her. For example, during the fasting month, refrain from eating lunch nearby. "From an early age, I learnt about diversity through firsthand experience rather than through the teachings of others. Learn to appreciate and tolerate," Lilin said. ${ }^{43}$ Meanwhile, Siti Rohmah said that differences are part of the human experience. ${ }^{44}$

Anis, from Lajnah Imaillah Jemaat Ahmadiyah Indonesia (JAI), contends that diversity is both good and dangerous. "It's important to understand the differences between individuals and to be accepting. It's not as good as it used to be when I lived in East Timor." ${ }^{45}$ Anis and her family lived in East Timor for a long period when she was a child. It was difficult for Anis to adapt as a Muslim who was a minority there. Although her surroundings and schoolmates are kind

\footnotetext{
41 Yulistia, interview, 12 April 2021.

42 Yohana, interview, 20 March 2021.

${ }^{43}$ Lilin Kurniawati, interview, 11 April 2021.

44 Siti Rohmah, interview, 11 April 2021.

45 Anis, interview, 12 April 2021.
} 
and respectful, Anis and her family were overwhelmed with anxiety as a minority, especially during the socio-political upheaval leading up to East Timor's independence. When East Timor gained independence, Anis's family moved to Yogyakarta. Anis, on the other hand, acknowledges that she still corresponds with her childhood friends there, even though they are of different faiths and nationalities.

Other informants, including Ayu, Sri Pratiwi Dewi, Lili, and Dian, agreed that diversity necessitates mutual respect and tolerance because peace should be brought through plurality, not the other way around. Meanwhile, Bonnie highlighted that the truth of diversity must be seen first in ourselves, then in our families, communities, and so on. "For example, when we dine together, there are many kinds of food available at the dining table, each member of the family has distinct tastes," said Bonnie, a senior activist for the women's movement in Yogyakarta. ${ }^{46}$

According to the many views of diversity presented above, they all agree that diversity, as well as difference, is sunnatulläh, something that cannot be avoided. Therefore, communication is required to bridge the existing differences. Mutual understanding, mutual respect, and tolerance will emerge through dialogue.

\section{Dialogue of Action}

The informants' perspectives on interfaith dialogue differed. Inter-religious dialogue, according to Yohana, is "a debate or exchange of ideas across religions/beliefs, and what is discussed is not simply about worship or belief." ${ }^{47}$ Interfaith dialogue, according to Anis, is "to know and understand the needs of each side in dialogue." "48 Meanwhile, two essential terms in inter-religious dialogue, according to Sri Pratiwi Dewi ${ }^{49}$ and Dian, ${ }^{50}$ are mutual respect and tolerance, which create positive relationships between people of different faiths. Inter-religious conversation, according to Lilin, ${ }^{51}$ will not take place unless people feel comfortable opening to people of different religions and beliefs. Yulistia feels that interfaith discussion

\footnotetext{
46 Poniyem Bonnie Kertaredja, interview, 12 April 2021.

47 Yohana, interview, 20 March 2021.

48 Anis, Yogyakarta, 12 April 2021.

49 Sri Pratiwi Dewi, interview, 20 March 2021.

${ }^{50}$ Dian, Yogyakarta, 20 March 2021.

${ }^{51}$ Lilin Kurniawati, interview, 11 April 2021.
} 
is important because it "teaches us about other religions and their differences." 52

There are some interesting themes in interfaith dialogue based on various perspectives, including debate, interaction, knowing, understanding, appreciating, and differences. Inter-religious dialogue, according to them, is having communication and meeting individuals from various religions or beliefs to identify and understand differences to build mutual respect and tolerance. This is consistent with the concept of dialogue as defined by Leonard Swidler, founder of the Dialogue Institute at Temple University. According to him, interreligious dialogue is "a two-way communication between persons who hold significantly differing views on a subject, with the purpose of learning more truth about the subject from the other." ${ }^{53}$

Most informants agreed that the SRILI Bakoelan program is a model of inter-religious dialogue, particularly for "dialogue of action." SRILI Bakoelan, according to Aant, the administrator of the Yogyakarta Kevikepan's Commission for Interreligious Relations and Beliefs, is a form of dialogue of action. Nana agrees that SRILI Bakoelan is a type of dialogue of action since it involves working together regardless of background (religion, ethnicity, etc.)..$^{54}$

Meanwhile, Anis said that there is communication in the WhatsApp group as well, even if they don't know one other yet. Meanwhile, Yohana stated that the SRILI Bakoelan program is part of inter-religious dialogue since it promotes understanding between people of different faiths. Yulistia gave a particular explanation, stating that "SRILI Bakoelan can be considered as inter-religious dialogue through economic empowerment." 55

The activities carried out by SRILI Bakoelan, which include a series of seminars, intensive training, providing online market media through FB and IG, a market day under the name "Rabunya SRILI" (Wednesday's SRILI) in the WhatsApp group of Srikandi Lintas Iman, and "Sabtu SRILI Sinau," (SRILI Saturday Learning) are a form of joint action and cooperation that, according to Swidler, is part of

\footnotetext{
52 Yulistia, interview, 12 April 2021.

53 Leonard Swidler, What Is Dialogue? Retrieved from Dialogue Institute https://dialogueinstitute.org/what-is-dialogue

${ }^{54}$ Nana Karolina, interview, 20 March 2021.

55 Yulistia, interview, 12 April 2021.
} 
the second model of interfaith dialogue, called "dialogue hand." 56 The combined action was strengthened further by the "Nglarisi Dagangan Teman" campaign, which involved members of Bakoelers as well as members of the SRILI community at large. This movement not only involves buying each other's products from SRILI Bakoeler but also marketing Bakoelers' products through WhatsApp status, Instagram, and Facebook, as well as oral chain of communication (getok tular)." 57

According to Thomas Thangaraj, who divides inter-religious dialogue into four types namely, dialogue of living, dialogue of action, theological dialogue, and spiritual dialogue, SRILI Bakoelan clearly falls within the second model of dialogue. He said that dialogue of action refers to when people of all religions work together to improve themselves and liberate humans from ignorance, poverty, prejudice, and oppression." 58 SRILI Bakoelan's series of economic empowerment projects illustrate what Thangaraj intended in this context. The SRILI Bakoelan program is carried out by individuals of all religions/beliefs based on collaboration and volunteers, with the goal of improving capacity, knowledge, skills, networks, and economic possibilities, both individually and in the community. Furthermore, SRILI Bakoelan's tangible efforts, in conjunction with the movement of Nglarisi Dagangan Teman, have represented a concrete attempt to liberate its members from economic slump and poverty. These different initiatives are taken seriously and on a continual basis.

For SRILI members, SRILI Bakoelan may be described as a place for reaffirming and enhancing the interfaith dialogue that has already been practiced. Siti Rohmah stated that she was becoming increasingly aware that the SRILI Bakoelan activity was part of interreligious dialogue. Siti, who sold Ayam Ungkep (chicken's steam) and grilled rice, was first hesitant to sell her products to non-Muslim SRILI members. However, after receiving an order from Christian and Catholic acquaintances, two of whom became devoted clients. She said:

"Some of my customers are Nur (Penghayat community), Rev.

Kristi (Christian), and Yohana (Catholic). They bought my

56 Leonard Swidler, Dialogue for Interreligious Understanding: Strategies for the Transformation of Culture-Shaping Institutions. New York: Palgrave MacMillan, 2014.

57 Javanese term which means "communicated orally".

58 M. Thomas Thangaraj, The Common Task: A Theology of Christian Mission (Nashville: Abingdon Press, 1999). 
stuff without hesitation, as if there were no obstacles, even though I am Muslim. Thus, I feel a sense of selfsatisfaction...... I can also visit Rev. Kristi. I mean, it is a whole different environment from what we are used to. It turns out that the difference is what we perceive to be different, after all we are all human. I have also met Asih, a kindergarten teacher; I assumed she was Muslim, but evidently, she's Catholic. I was first concerned that my meal would be rejected. But they did not. They like to eat and praise about how great it is. And it has its own sense of fulfillment." 59

Yohana had the same reservations when she wanted to promote the sale of one of the Bakoelers, mukenal rukub (Prayer cloth for Muslim women). She is cautious about promoting rukub/mukena to her Catholic community. Then she questioned and discussed it with her colleagues in SRILI, and eventually, her doubts were gone. She promotes mukena to his community with good intentions and the principle of mutual support. Although, the community is Catholic, they may also have Muslim friends or family who might need and want to buy the mukena. This intriguing encounter between Siti and Yohana demonstrates the existence of a genuine dialogue of action.

\section{Conclusion}

SRILI community has responded to the pandemic's impact by implementing economic empowerment program called SRILI Bakoelan. The program activities including conducting a series of seminars, trainings, and mentoring programs; providing online marketspaces on Facebook and Instagram; and arranging a market day called "Rabunya SRILI" (Wednesday's SRILI) through a WhatsApp group. In addition, the Bakoelers have created "Sabtu SRILI Sinau" (SRILI Saturday Learning) to develop their knowledge and online business skills. The programs involved interfaith women's MSME as a manifestation of the solidarity and empathy grown since the community's inception and later became one of SRILI's core values.

The SRILI Bakoelan is a more structured type of solidarity action that has an impact on personal, family, and community transformation. SRILI Bakoelers, both individually and as a family, can satisfy basic needs, prevent poverty, and strengthen family bonding. For some SRILI Bakoelers, the initiative improved their income amid

59 Siti Rohmah, interview, 11 April 2021. 
the pandemic. While at the community level, the initiatives are improving the emotional and social connection among members, encouraging creativity in problem solutions, and strengthening as well as broadening networks. This has indirectly created community resilience because the foundation of community resilience is solidarity, collaboration, and empathy, reinforced by the ability to adapt and innovate in addressing shared challenges.

Community economic empowerment not only contributes considerably to community economic growth but is also an important component of community resilience. SRILI Bakoelan's numerous economic empowerment programs have not only enhanced Bakoelers' knowledge and abilities but have also generated chances for business development. With the principle of "women supporting women," they share and care for one another to increase access to knowledge, markets, and other services. Furthermore, the list of beneficiaries is growing, not limited to SRILI members but also the public who might benefit from the initiatives. It can be concluded that the SRILI community economic empowerment initiative has had multiple effects. It is possible since the program's approach is cross-faith and cross-generational, utilizing various digital platforms such as Zoom, Facebook, Instagram, YouTube, and Whatsapp groups. Thus, SRILI Bakoelan's economic empowerment program has fostered an expansion in the creative ummah economy's potential in the family, community, and beyond.

The SRILI Bakoelan also creates a dialogue space for Bakoelers. Women from different backgrounds are deliberately eager to participate in interfaith activities by joining SRILI Bakoelan. The aforementioned "Dialogue Action" has also manifested the movement of "Nglarisi Dagangan Teman" and in the promotion of the product among Bakoelers as well as SRILI's members. The researchers would like to emphasize that social solidarity, social linking, and social bonding are valuable assets that a community may use to constantly adapt in establishing interfaith dialogue spaces and responding to social challenges.

\section{References:}

\section{Books and Journals}

Amri, Andi. "Dampak Covid-19 Terhadap UMKM di Indonesia." Jurnal Brand, Vol 2 No 1, (2020): 123-130. 
Baidhawi, Zakiyuddin. Fikih Kebhinekaan; Piagam Madinah dan Pancasila, Prinsip-Prinsip Kebidupan Bersama dalam Berbangsa dan Bernegara. Bandung: Mizan Pustaka, 2015.

Chairani, Ikfina. "Dampak Pandemi COVID-19 dalam Perspektif Gender di Indonesia." Jurnal Kependudukan Indonesia, Edisi Khusus Demografi dan COVID-19, (July, 2020): 39-42.

Diamond, Michael. "Community Economic Development: A Reflection on Community, Power, and the Law." The Jurnal of Small and Emerging Bussiness Law, vol 8, (2004), 153-155.

Drolet, Julie et. al. "Women Rebuilding Lives Post-Disaster: Innovative Community Practices for Building Resilience and Promoting Sustainable Development." Journal Gender \& Development, vol. 3 (3), (2015).

Emery, Mary and Flora, Cornelia. "Spiraling-Up: Mapping Community Transformation with Community Capitals Framework." Community Development, 37/1, (2006): 19-35. DOI: 10.1080/15575330609490152.

Fatihaturrohmah and Ichsan, Ahmad Shofiyuddin. "Gerakan Komunitas Perempuan Srikandi Lintas Iman.” Jurnal PAI Raden Falah, vol 1 no 4, (2019): 425-444.

Huberman, M. B. Qualitative Data Analysis: A Source Book of New Methods. London: Sage Publication, 1998.

Juita, Florentina. "Peran Perempuan Pedagang Sayur Keliling dalam Menopang Ekonomi Keluaga pada Masa Pandemi COVID-19 di Kelurahan Pagesangan Kecamatan Mataram Kota Mataram." CIVICUS: Pendidikan-Penelitian-Pengabdian, Pendidikan Pancasila dan Kewarganegaraan, 8 (2), (September, 2020): 100-107.

Madu, Christian N. H and Kuei, Cua-Hua, ed. Handbook of Disaster Risk Reduction and Management. Singapore: WSPC, 2018.

Nair, S. Nanthini and Tamara. "COVID-19 and the Impacts on Women." NTS Insigbt, No. IN20-05, RSIS Centre for Non-Traditional Security Studies (NTS Centre), Nanyang Technological University Singapore, (2020).

Noor, Nina Mariani. "Srikandi Lintas Iman: Religiosity in Diversity." Journal Research in the Social Scientific Study of Religion, vol. 30, (2019): 181-192. http://doi:10.1163/9789004416987_011.

Pongpindan, Alfriyani. "Srikandi Lintas Iman di Yogyakarta: Sebuah Model Spiritualitas Keugaharian dalam Moderasi Beragama." A thesis at Interdisciplinary Islamic Studies, Graduate Program, UIN Sunan Kalijaga, Yogyakarta, 2020.

Sa'adah, Sokhibatul. "Peran Komunitas Srikandi Lintas Iman (Srili) dalam Berpartisipasi Menciptakan Perdamaian Antar Umat Beragama Di Yogyakarta." A thesis of under-graduate program, the Faculty of 
Theology and Islamic Thought, UIN Sunan Kalijaga, Yogyakarta, 2019.

Soekanto, Soerjono. Sosiologi Suatu Pengantar. Jakarta: Raja Grafindo Persada, 2014.

Soemarjan, Selo. Social Change in Yogyakarta. New York: Cornel University Press, 1962.

Srikandi Lintas Iman. "Narasi Laporan Akhir Program Pemberdayaan Ekonomi Srikandi Lintas Iman.” Yogyakarta: 2020.

Sugiri, Dani. "Menyelamatkan Usaha Mikro, Kecil dan Menengah dari Dampak Pandemi Covid-19." Fokus Bisnis: Media Pengkajian Manajemen dan Akuntansi, 19 (1), (2020): 76-86. http://doi:10.32639/fokusbisnis.v19i1.575

Sugiri, Dani. "Menyelamatkan Usaha Mikro, Kecil dan Menengah dari Dampak Pandemi Covid-19." Jurnal Fokus Bisnis: Media Pengkajian Manajemen dan Akuntansi, vol 19, no 1, (2020): 76-86. http://doi.org/10.32639/fokusbisnis.v19i1.575

Temali, Mihailo. The Community Economic Development Handbook. USA: Amherst H. Wilder Foundation, 2002.

Thangaraj, M. Thomas. The Common Task: A Theology of Christian Mission. Nashville: Abingdon Press, 1999.

The Intergovernmental Panel on Climate Change (IPPC). Managing the Risks of Extreme Events and Disasters to Advance Climate Change Adaptation. New York: Cambridge University Press, 2012.

UN Women, Policy Brief No. 15. "Addressing the Economic Fallout of Covid-19: Pathways and Policy Options For A Gender-Responsive Recovery." 2020.

Wahyuningtyas, Retno et. al. "Srikandi Lintas Iman: Praktik Gerakan Perempuan dalam Menyuarakan Perdamaian di Yogyakarta." Jumal Sosiologi Reflektif, vol.13 (2), (2020): 293-312.

\section{Website}

https://data.unwomen.org/sites/default/files/inline-

files/Report_Counting $\% 20$ the $\% 20$ Costs $\% 20$ of $\% 20$ COVID-

19_Bahasa.pdf

https://kemenpppa.go.id/index.php/page/read/29/2921/survei-menilaidampak-covid-19-perempuan-memikul-beban-lebih-beratdibandingkan-laki-laki

https://reliefweb.int/sites/reliefweb.int/files/resources/Defining-

Disaster-Resilience-summary_0.pdf

https://www.kemenpppa.go.id/index.php/page/read/31/2707/kdrt-

mengintai-di-tengah-pandemi

https://www.merriam-webster.com/dictionary/empower 
https://www.unwomen.org/en/digital-

library/publications/2020/06/policy-brief-addressing-the-economicfallout-of-covid-19

www.communitydevelopment.com.au

https://wps-indonesia.com/rekomendasi-publik/

\section{Interview}

Aant, 12 April 2021.

Anis, 12 April 2021.

Dian, 20 March 2021.

Dwi Rahayu, 18 April 2021.

Lilin Kurniawati, 11 April 2021.

Mustaghfiroh Rahayu, 11 April 2021.

Nana Karolina, 20 March 2021.

Poniyem Bonnie Kertaredja, 12 April 2021.

Resti, 12 April 2021.

Siti Rohmah, 11 April 2021.

Sri Pratiwi Dewi, 20 March 2021.

Yohana, 20 March 2021.

Yulistia, 12 April 2021. 